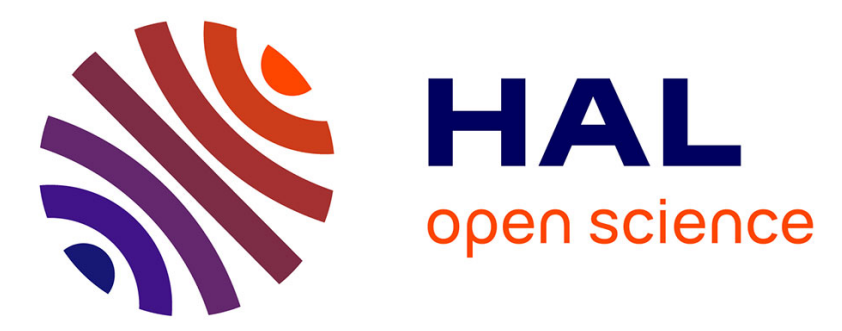

\title{
Erythropoietin enhances whole body lipid oxidation during prolonged exercise in humans
}

Corinne Caillaud, Philippe Connes, Helmi Ben Saad, Jacques Mercier

\section{To cite this version:}

Corinne Caillaud, Philippe Connes, Helmi Ben Saad, Jacques Mercier. Erythropoietin enhances whole body lipid oxidation during prolonged exercise in humans. Journal of Physiology and Biochemistry, 2015, 71 (1), pp.9-16. 10.1007/s13105-014-0374-8 . hal-01756260

\section{HAL Id: hal-01756260 \\ https://hal.umontpellier.fr/hal-01756260}

Submitted on 9 Sep 2018

HAL is a multi-disciplinary open access archive for the deposit and dissemination of scientific research documents, whether they are published or not. The documents may come from teaching and research institutions in France or abroad, or from public or private research centers.
L'archive ouverte pluridisciplinaire HAL, est destinée au dépôt et à la diffusion de documents scientifiques de niveau recherche, publiés ou non, émanant des établissements d'enseignement et de recherche français ou étrangers, des laboratoires publics ou privés. 


\title{
Erythropoietin enhances whole body lipid oxidation during prolonged exercise in humans
}

\author{
Corinne Caillaud • Philippe Connes • \\ Helmi Ben Saad • Jacques Mercier
}

\begin{abstract}
Animal studies have suggested that erythropoietin, besides its well-known hematopoietic effects, can modulate metabolism and prevent fat accumulation. We investigated the effects of repeated injections of recombinant human erythropoietin (EPO) on the balance of substrate oxidation during aerobic exercise in humans. Twelve healthy aerobically trained males received subcutaneously either moderate dose of EPO (50 U/kg, EPO) or saline injections ( $\mathrm{NaCl} 0.9 \%$,
\end{abstract}

\section{Caillaud $(\bowtie)$}

Exercise Health and Performance, Faculty of Health Sciences, The University of Sydney,

75 East Street, LidcombeNSW 1825 Sydney, Australia

e-mail: corinne.caillaud@sydney.edu.au

\section{P. Connes}

UMR Inserm U1134, Université des Antilles et de la Guyane,

Pointe à Pitre, Guadeloupe, France

\section{P. Connes}

Laboratory of Excellence GR-Ex "The Red Cell: from genesis to death", PRES Sorbonne,

Paris Cité, France

P. Connes

Institut Universitaire de France,

Paris, France

H. Ben Saad

Laboratory of Physiology, Faculty of Medicine of Sousse, University of Sousse,

Sousse, Tunisia

J. Mercier

Inserm U1046, University of Montpellier 1-CHRU,

Montpellier, France control) three times a week for 4 weeks. Body weight, $\%$ fat, maximal aerobic capacity, and substrate utilization during exercise were assessed before and after treatment, while hemoglobin and hematocrit were monitored regularly during the treatment. Carbohydrate and fat oxidation were evaluated via indirect calorimetry, during a submaximal exercise performed at $75 \%$ of the participants' maximal aerobic capacity $\left(V^{\circ} O_{2 \max }\right)$ for $60 \mathrm{~min}$. Results showed that 4 weeks of EPO treatment significantly enhanced fat oxidation $(+56 \%$ in EPO versus $-9 \%$ in control) during exercise, independent of its effects on hematological parameters or $V O_{2 \max }$. This study shows that EPO can modulate substrate utilization during exercise, leading to enhanced fat utilization and lower use of carbohydrates. This opens new research directions exploring whether systemic EPO levels, in physiological conditions, participate to the modulation of fat oxidation.

Keywords Indirect calorimetry - Metabolism · Submaximal exercise $\cdot$ Lipid oxidation $\cdot$ Human

\section{Introduction}

Erythropoietin is a glycosylated protein hormone, well known as the primary factor controlling red blood cells formation. Since the introduction, in 1989, of human recombinant erythropoietin (EPO) for the treatment of anemia in end-stage kidney disease (ESKD), studies showed that EPO also has extra-hematopoietic effects, primarily as a tissue protective agent with anti-oxidant 
and anti-apoptotic properties [3, 28, 33]. Recently, EPO has emerged as a potential modulator of metabolism. Animal studies showed that exogenous EPO [12, 15] prevented increases in body weight and fat mass in mice fed with a high-fat diet. Models using genetically modified mice (Tg-mice) expressing the erythropoietin receptor (EPOR) only in hematopoietic cells, showed that disruption of EPO signaling in metabolic tissues quickly led to the development of obesity and insulin resistance [29]. Conversely, in other models, mice overexpressing erythropoietin were protected against obesity [17]. In vitro, skeletal muscle homogenates overexpressing EPO displayed increased oxidation of exogenous palmitate [15]. These animal studies suggest that the balance between fat utilization and storage may be modulated by EPO. Whether EPO promotes fat oxidation or modifies body composition in humans is still unknown. Early investigations conducted in patients with ESKD did not report modifications of body mass index [2, 20, 31]. In young healthy subjects, acute dosage with EPO increases energy expenditure at rest within $2 \mathrm{~h}$ following injection [6] with non-significant changes in fat oxidation. However, the metabolic influence of EPO in humans may exert its full effect during muscle activity, when fuel utilization increases in response to energy demand. In that case, an increased utilization of fat by active muscles will make a significant difference in the balance between fat storage and utilization.

We hypothesized that EPO treatment could promote fat oxidation during exercise. To verify this hypothesis, we investigated the balance of substrate utilization during aerobic exercise in healthy subjects both before and after 4 weeks of moderate dose EPO treatment.

\section{Materials and methods}

\section{Study design}

This study is part of a larger project $[7,8-10]$ and has received ethical approval from the local ethical comity (Comité Consultatif de Protection des Personnes en Recherche Biomédicale de Montpellier, Hôpital Saint Eloi, Montpellier, France). The study has been conducted according to the principles expressed in the Declaration of Helsinki. The protocol (Fig. 1) was explained to participants who provided written informed consent. The metabolic study included 12 healthy aerobically trained young men randomly assigned to either EPO
( $n=6,26.8 \pm 4.1$ years) or control group $(n=6,26.8 \pm$ 6.0 years). Participants first attended the laboratory for screening, and baseline measures of anthropometry, blood parameters, and maximal aerobic capacity $\left(V^{\circ} O_{2 \max }\right)$. Body composition was assessed with a multi-frequency $(1,5,10,50,100 \mathrm{kHz})$ bioelectrical impedance-meter (HUMAN IM Scan, Dietosystem, Milan, Italy). Blood samples were collected at rest and further analyzed (Pentra 120 Retic Hematology Analyzer, France). Within 1 week, participants performed a 60min steady state aerobic exercise test at a workload corresponding to $75 \%$ of $V^{\circ} O_{2 \max }$ (LOAD1-pre). They then received subcutaneous injections of EPO (Eprex ${ }^{\circledR}$, France), $50 \mathrm{U} / \mathrm{kg}$ three times a week (EPO group) or $\mathrm{NaCl} 0.9 \%$ (control group) for 4 weeks. Both groups also received a daily oral dose of iron sulfate (Ferograd ${ }^{\circledR}$, Abbott Laboratories, France), vitamin $B_{9}$ (SpeciaFoldine ${ }^{\circledR}$, Théraplix Aventis, France), and vitamin $B_{12}\left(G{ }^{\circledR}{ }^{\circledR}\right.$, Gerda Laboratories, France) $[8,10]$. Hematocrit (Hct), hemoglobin $(\mathrm{Hb})$, and training characteristics were followed during the whole experiment. Hct was monitored three times weekly and, for ethical reasons, dose was adjusted to maintain Hct below $50 \%$. EPO treatment was stopped and injections done with saline when Hct reached $50 \%$. After the 4-week treatment period, body weight, percentage of fat and $V$ $\mathrm{O}_{2 \max }$ were re-assessed. Constant load exercise was performed at $75 \%$ of $V{ }^{\circ} O_{2 m a x}$ pre- and post-treatment. All participants were physically active, trained four to five times a week and were asked to maintain their habitual physical activity during the study period. The training load was quantified weekly for each subject using a model that takes into account both the volume and the intensity of each training session [23]. For each participant, blood data were followed during a wash-out period of 3 weeks or until $\mathrm{Hct}, \mathrm{Hb}$, and reticulocytes count were back to baseline levels. The total follow-up for each individual averaged 63 days. Participants were not allowed to participate in any competitive or official sporting event before normalization of $\mathrm{Hct}$ and $\mathrm{Hb}$ (at least 61 days).

\section{Exercise tests}

All exercise tests were performed on an electrically braked cycle ergometer (Jaeger Ergoline 800S, Germany) and gas exchanges were continuously sampled and analyzed by an automated system (Jaeger Oxycon 


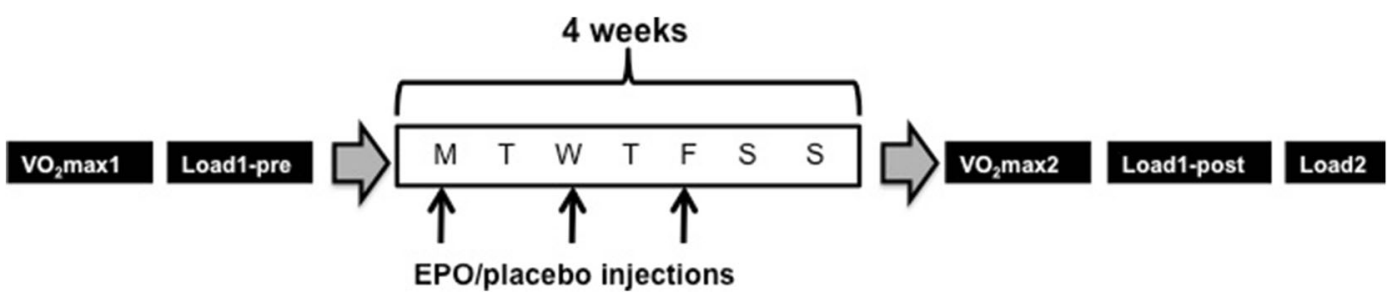

Fig. 1 Study design. Participants performed a $\mathrm{VO}_{2 \max }$ test $\left(V O_{2 \max } 1\right)$ and a 1 -h constant load exercise at $75 \%$ of $V$ $\mathrm{O}_{2 \max }$ before EPO treatment (LOAD1-pre). During the 4 weeks of the experiment, they received subcutaneous injections of either $\mathrm{EPO}\left(\right.$ Eprex $\left.^{\circledR}, 50 \mathrm{U} / \mathrm{kg}\right)$ or saline $(\mathrm{NaCl} 0.9 \%)$ three times a week. On week 5, participants performed the second $\mathrm{VO}_{2 \max }$ test

Alpha, Germany). $V^{\circ} O_{2 \max }$ was determined by using a progressive exercise test as previously described [8]. The 60-min constant load aerobic exercises were performed between 8:00 a.m. and 10:00 a.m. after a 12-h overnight fast. Subjects were asked to repeat the same diet before all subsequent trials and to refrain from exercise the day before each exercise test. The target workload was calculated from the pre-treatment $V$ $\mathrm{O}_{2 \max }$ test and each participant exercised at this load pre- (LOAD1-pre) and post-treatment (LOAD1-post). Since we expected an increase of $V O_{2 \max }$ following treatment, participants also performed exercise at $75 \%$ of post-treatment $V{ }^{\circ} O_{2 \max }$ (LOAD2). Carbohydrate and fat oxidation during exercise were assessed via indirect calorimetry. This method has been validated [26] against stable isotope technique during steady state exercise. Oxygen uptake $\mathrm{V}^{\circ} \mathrm{O}_{2}, \mathrm{CO}_{2}$ output $\mathrm{V}^{\circ} \mathrm{CO}_{2}$, and respiratory exchange ratio $\left(\mathrm{RER}=\mathrm{V}^{\circ} \mathrm{CO}_{2} / \mathrm{V}^{\circ} \mathrm{O}_{2}\right.$ ) were recorded at rest and during exercise. After a period of $15 \mathrm{~min}$ in sitting position on the bicycle, resting data were collected for $10 \mathrm{~min}$, as the subject was quietly seated in the same position with no bodily movement. During exercise, gas exchange data were collected for $5 \mathrm{~min}$ every $10 \mathrm{~min}$. The data recorded during the first $10 \mathrm{~min}$ of exercise, as the subjects were still adjusting to the exercise intensity, were not taking into account in the analysis. Data were filtered for aberrant values and then averaged over each 5-min period. Calculation of carbohydrate and fat oxidation was made according to the table of non-protein respiratory exchange ratio (RER) [24]:

Carbohydrate oxidation rate $\left(\mathrm{g} \cdot \mathrm{min}^{-1}\right)$

$=4.585 \times \mathrm{V}^{\circ} \mathrm{CO}_{2}-3.226 \times \mathrm{V}^{\circ} \mathrm{O}_{2}$

Fat oxidation rate $\left(\mathrm{g} \cdot \mathrm{min}^{-1}\right)$ $=1.695 \times \mathrm{V}^{\circ} \mathrm{O}_{2}-1.701 \times \mathrm{V}^{\circ} \mathrm{CO}_{2}$
$\left(V O_{2 \max } 2\right.$ ) followed by two 1-h constant load exercises performed at $75 \%$ of $\mathrm{VO}_{2 \max } 1$ (LOAD1-post) and $75 \%$ of $V{ }^{\circ}{ }_{2 \max }$ 2 (LOAD2). Each exercise was performed on separate days, with a 48-h recovery period between exercise tests

with $\mathrm{V}^{\circ} \mathrm{CO}_{2}$ and $\mathrm{V}^{\circ} \mathrm{O}_{2}$ expressed in liters per minute.

Statistical analysis

Data were tested for normality and equality of variance and analyzed using a two-way analysis of variance (ANOVA), i.e., groups (control versus EPO) with repeated measures, i.e., time (pre- versus post-treatment). Detailed analysis of fat oxidation during exercise was conducted using a two-way ANOVA with repeated measures including time (pre- versus post-treatment) and exercise (6 time points). Where relevant, specific effects were tested using a Bonferroni test for multiple comparisons. Correlations were investigated using the Pearson product-moment coefficient. The significance level for all comparisons was set at $P<0.05$. The statistical analysis was conducted with SPSS software (v. 20, IBM SPSS Statistics, Chicago, IL).

\section{Results}

Anthropometry and hematology

Participants were lean with an average body fat of $6.5 \%$ (Table 1). Four weeks of EPO treatment led to a small non-significant change in percentage of body fat (interaction between time and group: $F(1,10)=4.33, P=$ 0.076 , Table 1) with no modification of body weight $(P>0.05$, Table 1$)$. Hct and $\mathrm{Hb}$ were within normal range at baseline and increased significantly following EPO treatment (interaction between time and group: $F$ $(1,10)=18.7, P=0.002$ and $F(1,10)=9.78, P=0.011$ for $\mathrm{Hct}$ and $\mathrm{Hb}$, respectively; Table 1). As a result, both Hct and $\mathrm{Hb}$ were significantly elevated in EPO group 
Table 1 Anthropometry, blood, and submaximal exercise data

Exercise data for RER and carbohydrate oxidation are calculated over the last $20 \mathrm{~min}$ of exercise. Values are mean $\pm \mathrm{SD}$

$* P<0.05$, EPO versus control (Bonferroni test)

$* * P<0.05$, for interaction between time and group (two-way ANOVA with repeated measures) $* * * P<0.05$, pre versus post within group (Bonferroni test)

\begin{tabular}{|c|c|c|c|}
\hline & Time & $\begin{array}{l}\text { Control }(n= \\
6)\end{array}$ & $\mathrm{EPO}(n=6)$ \\
\hline \multirow[t]{2}{*}{ Weight $(\mathrm{kg})$} & Pre & $69.5 \pm 6.7$ & $69.8 \pm 8.4$ \\
\hline & Post & $69.9 \pm 6.9$ & $69.8 \pm 8.3$ \\
\hline \multirow[t]{2}{*}{ Fat $(\%)$} & Pre & $6.3 \pm 2.2$ & $6.7 \pm 1.6$ \\
\hline & Post & $6.7 \pm 2.6$ & $5.8 \pm 0.8$ \\
\hline \multirow[t]{2}{*}{$\mathrm{Hb}\left(\mathrm{g} \cdot \mathrm{dl}^{-1}\right) * *$} & Pre & $14.6 \pm 0.9$ & $14.8 \pm 0.4$ \\
\hline & Post & $14.5 \pm 1.5$ & $16.2 \pm 1.0 * * * *$ \\
\hline \multirow[t]{2}{*}{$\operatorname{Hct}(\%)^{* *}$} & Pre & $44.3 \pm 2.9$ & $44.0 \pm 2.9$ \\
\hline & Post & $44.2 \pm 4.1$ & $49.4 \pm 3.7 *, * * *$ \\
\hline \multirow{2}{*}{$V O_{2 \max }\left(\mathrm{ml}^{\prime} \mathrm{kg}^{-1} \cdot \min ^{-1}\right)^{* *}$} & Pre & $63.0 \pm 4.8$ & $61.9 \pm 4.6$ \\
\hline & Post & $62.0 \pm 6.4$ & $65.8 \pm 5.9 * * *$ \\
\hline \multirow[t]{2}{*}{ Resting fat oxidation rate (g.min ${ }^{-1}$ ) } & Pre & $0.10 \pm 0.04$ & $0.10 \pm 0.05$ \\
\hline & Post & $0.10 \pm 0.03$ & $0.16 \pm 0.07$ \\
\hline \multirow[t]{2}{*}{ Workload (W)* } & Pre (LOAD1) & $249 \pm 23$ & $247 \pm 31$ \\
\hline & $\begin{array}{l}\text { Post } \\
\quad \text { (LOAD2) }\end{array}$ & $250 \pm 23$ & $269 \pm 31$ \\
\hline \multirow[t]{2}{*}{ RER, LOAD1** } & Pre & $0.91 \pm 0.02$ & $0.92 \pm 0.04$ \\
\hline & Post & $0.92 \pm 0.02$ & $\begin{array}{l}0.89 \pm 0.02 * \\
\quad * * *\end{array}$ \\
\hline \multirow{2}{*}{$\begin{array}{l}\text { Carbohydrate oxidation rate, LOAD1 } \\
\left(\mathrm{g} \cdot \mathrm{min}^{-1}\right)^{* *}\end{array}$} & Pre & $3.52 \pm 0.37$ & $3.99 \pm 0.31$ \\
\hline & Post & $3.72 \pm 0.36$ & $3.26 \pm 0.37 * * *$ \\
\hline
\end{tabular}

following treatment compared to control and baseline $(P<0.05)$.

Exercise tests and substrate utilization during aerobic exercise

$V^{\circ} \mathrm{O}_{2 \max }$ levels before treatment showed that participants were aerobically fit with an average $V^{\circ} O_{2 \max }$ of $63.0 \pm 4.8 \mathrm{ml} \cdot \mathrm{kg}^{-1} \cdot \mathrm{min}^{-1}\left(4408 \pm 294 \mathrm{ml} \cdot \mathrm{min}^{-1}\right)$ and 61.9 $\pm 4.6 \mathrm{ml} \cdot \mathrm{kg}^{-1} \cdot \mathrm{min}^{-1}\left(4468 \pm 512 \mathrm{ml} \cdot \mathrm{min}^{-1}\right)$ in control and EPO, respectively (Table 1, no difference between groups). The training load was maintained with no statistical difference between groups and over time during intervention ( $P>0.05$, Fig. 2). $V^{\circ} O_{2 \max }$ increased in EPO group following treatment (interaction between time and group: $F(1,10)=5.28, P=0.044)$ and was unchanged in control. There was also a slight increase in maximal power output $(+7.3 \% P=0.07)$ in the EPO group. The average $V^{\circ} \mathrm{O}_{2}$ during LOAD1-pre exercise was $3.34 \pm 0.371 . \mathrm{min}^{-1}$ and $3.42 \pm 0.311 . \mathrm{min}^{-1}$ in control and EPO, respectively. After treatment, $\mathrm{V}^{\circ} \mathrm{O}_{2}$ during LOAD1-post was $3.32 \pm 0.42$ and $3.55 \pm 0.251 . \mathrm{min}^{-1}$ in control and EPO groups, respectively ( 75.5 of $\left.V^{\circ} O_{2 \max }\right)$. Metabolic data averaged over the last 20min of exercise (Table 1) shows that RER was significantly reduced in EPO compared to the control group for LOAD1-post (interaction between time and group: $F$ $(1,10)=8.89, P=0.014$, Table 1$)$ while carbohydrate oxidation rate was increased $(P<0.05$, Table 1$)$. Accordingly, fat oxidation rate was elevated following EPO treatment during exercise at same absolute load (time $\times$ group $F(1,10)=11.7, P=0.007$, Fig. $3 a)$ with no statistical difference between LOAD1-pre and LOAD2 $(F$ $(1,10)=1.78, P=0.211$, Fig. 3a). Analysis of data during the course of exercise confirmed that EPO increased fat oxidation at same absolute load (time $\times$ group interaction $F(1,10)=12.7, P=0.005$, Fig. $3 \mathrm{~b}, \mathrm{c})$, with a significant difference between groups from $30 \mathrm{~min}$ up to the end of exercise (ANOVA with repeated measures and post hoc comparison using Bonferroni correction, Fig. 3c). At no time point during exercise was fat oxidation at LOAD2 different between control and EPO $(F(1,10)=0.52, P=$ 0.48 , Fig. $3 \mathrm{~d})$. There was no significant relationship between $\mathrm{Hct}$ or $\mathrm{Hb}$ and fat oxidation rate during exercise at LOAD1 pre- or post-treatment $(P>0.05)$. 


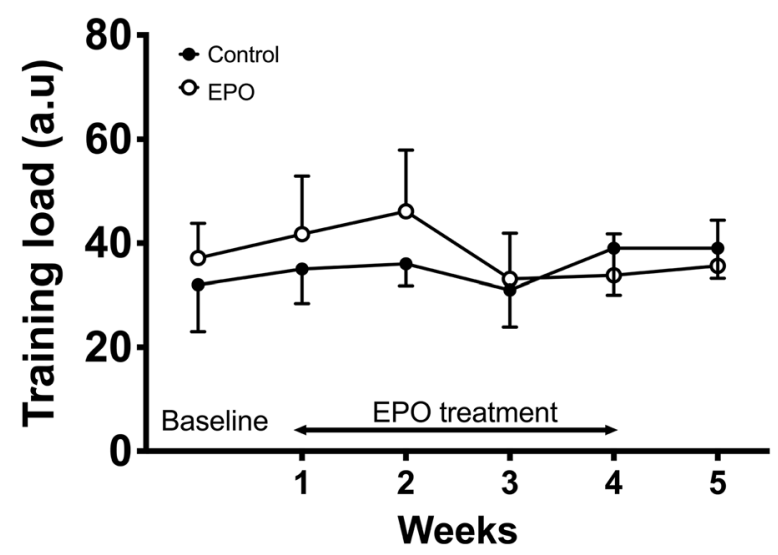

Fig. 2 Training load during 4 weeks of erythropoietin (EPO) treatment. Training load was evaluated a week before and during the whole treatment period in both groups. Training load was unchanged and did not differ between the control and EPO groups over the course of the study. Statistical analysis (two-way ANOVA with repeated measures) did not reveal statistical differences between groups or any interaction between time and groups. Control: control group, EPO: EPO-treated group, a.u: arbitrary units

\section{Discussion}

This study shows that a 4-week EPO treatment increased whole body fat oxidation during aerobic exercise in young healthy physically active males. The shift toward fat oxidation was not related to the enhanced aerobic capacity, or to $\mathrm{Hb}$ levels, suggesting a role for EPO in metabolism.

Studies conducted in ESKD patients suggested that long-term EPO treatment might alter metabolism in humans. In ESKD patients treated with EPO, plasma levels of triglycerides and total cholesterol $[18,21]$ were found reduced, while muscle glycogen content increased was associated with concomitant reduction in muscle fat [11]. In these patients with anemia, the metabolic changes observed following EPO treatment were thought to be mainly mediated by increased red blood cell count, $\mathrm{Hb}$ levels, and improved oxygen transport. In the present study, participants had normal $\mathrm{Hb}$ levels and the shift toward enhanced fat oxidation rate was not related to the changes in $\mathrm{Hb}$. This suggests that EPO itself, potentially in synergy with exercise training, promoted fat oxidation. This study is unique in investigating the metabolic effect of EPO treatment during submaximal exercise. Results suggest that key pathways, either in adipose tissue (leading to increased fatty acid availability) or in skeletal muscle (leading to enhanced uptake and oxidation), could be activated. In resting condition, no significant change in the balance of substrate utilization could be detected, and this is in agreement with a previous study conducted in young healthy subjects showing a nonsignificant trend toward enhanced whole body resting fat oxidation following a single EPO injection [6]. A recent study did not provide evidence for a synergetic effect between aerobic training and darbepoietin- $\alpha$ treatment in previously sedentary subjects [5]. However, the study did not investigate substrate utilization during exercise. In addition, the dosage regimen of erythropoiesisaccelerating agent (ESA), as well as the participants training status, training load, and duration of the interventions differed largely between that study and ours, and this could explain some of the discrepancies. Longer study duration generally leads to a progressive decline in ESA dosage in order to maintain $\mathrm{Hct}$ and $\mathrm{Hb}$ within acceptable limits, and this may reduce the extrahematopoietic effect of these agents.

The changes in RER and fat oxidation rate reported in the EPO group are in line with those reported following 5 to 12 weeks of aerobic training in previously untrained subjects $[22,25]$. Previous research shows that whole body lipid oxidation during exercise changes with the same pattern as muscle fat oxidation rate, although active muscles used a lower percentage of lipids than the whole body [13]. The data reported here suggest that fat oxidation increased either in active muscle or inactive tissues following EPO treatment. Muscle fat metabolism during exercise is controlled by numerous factors including adipose tissue lipolysis, fatty acid delivery to the muscle, and movement across both the muscle and the mitochondrial membranes [4]. Training status, diet, and fasting state also contribute to modulate fat oxidation during exercise [14]. In the present study, the latter factors were minimized (although not controlled) since all participants were aerobically trained and were asked to maintain both habitual training regimen and diet throughout the study. Relative exercise intensity during the 60 -min exercise was about $75 \%$ of $V^{\circ} O_{2 \max }$. At such exercise intensity, carbohydrate oxidation is the major source of energy; however, the capacity to oxidize fat plays a critical role in resistance to fatigue [1, 34]. Also, at that intensity, 70\% of the fat oxidized comes from plasma long chain fatty acid [32], although intramuscular triglyceride can also be a significant source of fatty acid $[22,25]$. The present study does not provide indications on whether the rise in total lipid oxidation is due to increased intramuscular or circulating fat oxidation. 
a

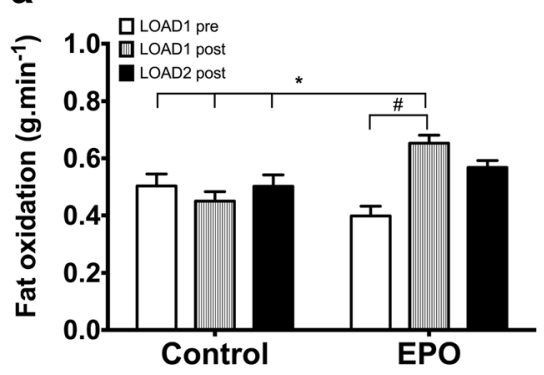

C

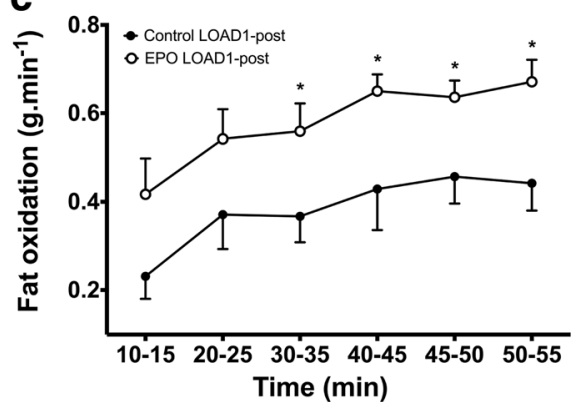

Fig. 3 Erythropoietin (EPO) treatment enhances fat oxidation rate during aerobic exercise. a Fat oxidation during the last $20 \mathrm{~min}$ of exercise at LOAD1-pre, LOAD1-post, and LOAD2 in both control and EPO groups. Statistical analysis (two-way ANOVA with repeated measures) indicated a significant interaction between time and groups and multiple comparisons with Bonferroni correction was used to assess specific effects between and within groups. ${ }^{*} P<0.05$ between groups, ${ }^{\#} P<0.05$ within group as shown on figure. b-d Fat oxidation in control and EPO groups

The current results show that fat oxidation rate was increased by EPO treatment at same absolute load and tended to be higher at same relative load. The lack of association between the increase in fat oxidation and the increase in $V{ }^{\circ} O_{2 \max }$ after EPO treatment suggests that the improvement of aerobic capacity was not a key factor in the metabolic adaptations induced by EPO injections. Another study investigating submaximal exercise, reported that 11 weeks of EPO treatment increased submaximal exercise performance (time to exhaustion measured at $80 \%$ of $V O_{2 \max }$ ) independent of the change in $V^{\circ} O_{2 \max }[30]$.

In mice, muscle and systemic EPO over-expression via electro-transfer led to increased palmitate oxidation in vitro and to upregulation of genes involved in lipid metabolism while genes implicated in insulin and glucose metabolism were downregulated [15]. This led to the hypothesis that EPO can promote fat metabolism in muscle. There is less evidence of such an effect in humans. The question of the presence of the EPOR in
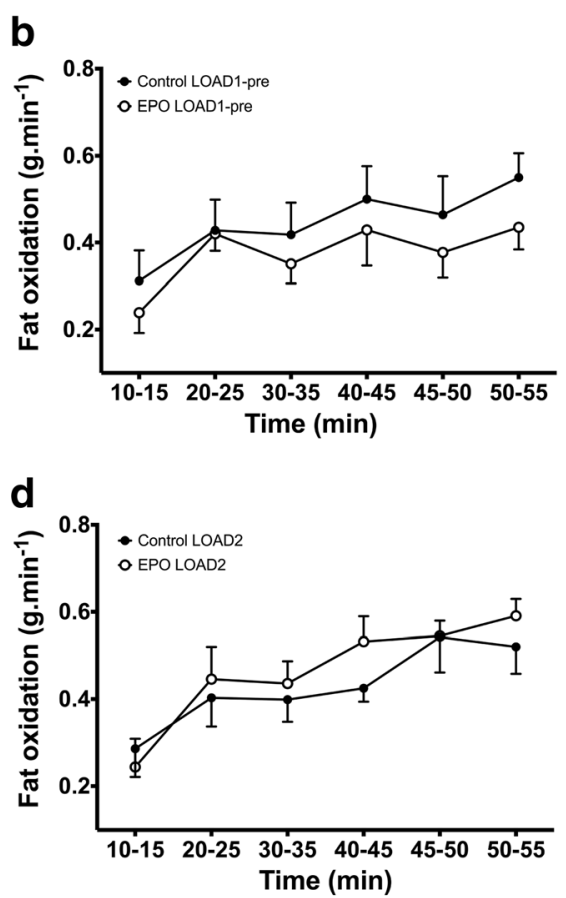

during $60 \mathrm{~min}$ of exercise performed at $75 \%$ of pre-treatment maximal oxygen uptake ( $\left.V \mathrm{O}_{2 \max }\right)$ b before (LOAD1-pre) and c after EPO treatment (LOAD1-post) and $\mathbf{d} 75 \%$ of post-treatment $V \mathrm{O}_{2 \max }$ (LOAD2). Statistical analysis (two-way ANOVA with repeated measures) indicated a significant interaction between time and groups, and multiple comparisons with Bonferroni correction was used to assess specific effects between groups. $* P<0.05$ between groups as shown on figure

human muscle has been raised, and studies have shown that EPOR is expressed in muscle tissue on sarcolemma and vascular cells [19]. It is interesting to note that one study showed that EPOR mRNA increased following exercise, suggesting a possible synergy between exercise and EPO [27]. It still remains to be established if EPOR is functional in human skeletal muscle. In young healthy untrained male subjects, EPO treatment has been reported to increase $\mathrm{Hct}, \mathrm{Hb}$, and $V^{\circ} \mathrm{O}_{2 \max }$ but does not seem to lead to major muscle adaptations [19]. In participants who did not train during the study, 15 weeks of EPO treatment (5000 U/injection, with injections once a week for the last 10 weeks) increased leg and pulmonary oxygen uptake but did not modify capillary density of muscle fibers cross-sectional area. The authors concluded that EPO exerted its main effect on aerobic capacity via increased oxygen transport and delivery, affecting $V O_{2 \max }$ [19]. Other studies showed that expression of some muscle proteins, such as the alpha 2 subunit of the $\mathrm{Na}^{+} / \mathrm{K}^{+}$pump, were modified by 
EPO treatment, although oxidative enzymes such as cytochrome $\mathrm{c}$ and hexokinase, and other major proteins involved in cross-membrane transport of metabolites, were not altered [16]. Acute EPO injection has also been studied in resting condition in human muscle and results did not demonstrate a significant effect on the activation of proteins involved in fat metabolism as ACC (acetylCoA-carboxylase) and AMPK (AMP-activated protein kinase) [6]. Increase fat availability via enhanced released of fatty acid from adipose tissue may be a key aspect of the modulation of fat oxidation during exercise.

In conclusion, this study shows for the first time that short-term EPO treatment has the potential to enhance fat oxidation during aerobic exercise. Although the understanding of the underlying mechanisms needs further investigations with a larger sample size, this raises the question of a role for native EPO in metabolism during exercise.

Acknowledgments The study has been conducted in the Clinical Physiology Department, Centre Hospitalier Régional Universitaire, Montpellier, France. The authors thank Ray Patton from the University of Sydney for his contribution.

\section{References}

1. Achten J, Jeukendrup AE (2004) Optimizing fat oxidation through exercise and diet. Nutrition 20:716-727

2. Borissova AM, Djambazova A, Todorov K, Dakovska L, Tankova T, Kirilov G (1993) Effect of erythropoietin on the metabolic state and peripheral insulin sensitivity in diabetic patients on haemodialysis. Nephrol Dial Transplant 8:93

3. Brines M, Grasso G, Fiordaliso F, Sfacteria A, Ghezzi P, Fratelli M, Latini R, Xie Q-W, Smart J, Su-Rick C-J, Pobre E, Diaz D, Gomez D, Hand C, Coleman T, Cerami A (2004) Erythropoietin mediates tissue protection through an erythropoietin and common beta-subunit heteroreceptor. Proc Natl Acad Sci U S A 101:14907-14912

4. Brooks GA, Mercier J (1994) Balance of carbohydrate and lipid utilization during exercise: the "crossover" concept. J Appl Physiol 76:2253-2261

5. Christensen B, Nellemann B, Larsen MS, Thams L, Sieljacks P, Vestergaard PF, Bibby BM, Vissing K, Stodkilde-Jorgensen H, Pedersen SB, Moller N, Nielsen S, Jessen N, Jorgensen JO (2013) Whole body metabolic effects of prolonged endurance training in combination with erythropoietin treatment in humans: a randomized placebo controlled trial. Am J Physiol Endocrinol Metab 305:E879-E889

6. Christensen B, Vendelbo MH, Krusenstjerna-Hafstrøm T, Madsen M, Pedersen SB, Jessen N, Moller N, Jorgensen JOL (2012) Erythropoietin administration acutely stimulates resting energy expenditure in healthy young men. J Appl Physiol 112:1114-1121

7. Connes P, Bouix D, Py G, Caillaud C, Kippelen P, Brun J-F, Varray A, Prefaut C, Mercier J (2004) Does exercise-induced hypoxemia modify lactate influx into erythrocytes and hemorheological parameters in athletes? J Appl Physiol 97: 1053-1058

8. Connes P, Caillaud C, Mercier J, Bouix D, Casties JF (2004) Injections of recombinant human erythropoietin increases lactate influx into erythrocytes. J Appl Physiol 97:326-332

9. Connes P, Caillaud C, Simar D, Villard S, Sicart M-T, Audran M (2004) Strengths and weaknesses of established indirect models to detect recombinant human erythropoietin abuse on blood samples collected 48-hr post administration. Haematologica 89:891-892

10. Connes P, Perrey SP, Varray A, Prefaut C, Caillaud C (2003) Faster oxygen uptake kinetics at the onset of submaximal cycling exercise following 4 weeks recombinant human erythropoietin (r-HuEPO) treatment. Pflugers Arch 447:231-238

11. Davenport A, King RF, Ironside JW, Will EJ, Davison AM (1993) The effect of treatment with recombinant human erythropoietin on the histological appearance and glycogen content of skeletal muscle in patients with chronic renal failure treated by regular hospital haemodialysis. Nephron 64:89-94

12. Foskett A, Alnaeeli M, Wang L, Teng R, Noguchi CT (2011) The effects of erythropoietin dose titration during high-fat diet-induced obesity. J Biomed Biotechnol 2011:373781

13. Friedlander AL, Jacobs KA, Fattor JA, Horning MA, Hagobian TA, Bauer TA, Wolfel EE, Brooks GA (2007) Contributions of working muscle to whole body lipid metabolism are altered by exercise intensity and training. Am J Physiol Endocrinol Metab 292:E107-E116

14. Helge JW, Richter EA, Kiens B (1996) Interaction of training and diet on metabolism and endurance during exercise in man. J Physiol 492(Pt 1):293-306

15. Hojman P, Brolin C, Gissel H, Brandt C, Zerahn B, Pedersen BK, Gehl J (2009) Erythropoietin over-expression protects against diet-induced obesity in mice through increased fat oxidation in muscles. PLoS One 4:e5894

16. Juel C, Thomsen JJ, Rentsch RL, Lundby C (2007) Effects of prolonged recombinant human erythropoietin administration on muscle membrane transport systems and metabolic marker enzymes. Eur J Appl Physiol 102:41-44

17. Katz O, Stuible M, Golishevski N, Lifshitz L, Tremblay ML, Gassmann M, Mittelman M, Neumann D (2010) Erythropoietin treatment leads to reduced blood glucose levels and body mass: insights from murine models. J Endocrinol 205:87-95

18. Khedr E, El-Sharkawy M, Abdulwahab S, Eldin EN, Ali M, Youssif A, Ahmed B (2009) Effect of recombinant human erythropoietin on insulin resistance in hemodialysis patients. Hemodial Int 13:340-346

19. Lundby C, Hellsten Y, Jensen MBF, Munch AS, Pilegaard H (2008) Erythropoietin receptor in human skeletal muscle and the effects of acute and long-term injections with recombinant human erythropoietin on the skeletal muscle. J Appl Physiol 104:1154-1160

20. Mak RH (1996) Correction of anemia by erythropoietin reverses insulin resistance and hyperinsulinemia in uremia. Am J Physiol 270:F839-F844 
21. Mak RH (1998) Metabolic effects of erythropoietin in patients on peritoneal dialysis. Pediatr Nephrol 12:660-665

22. Martin WH, Dalsky GP, Hurley BF, Matthews DE, Bier DM, Hagberg JM, Rogers MA, King DS, Holloszy JO (1993) Effect of endurance training on plasma free fatty acid turnover and oxidation during exercise. Am J Physiol 265:E708-E714

23. Millet GP, Candau RB, Barbier B, Busso T, Rouillon JD, Chatard JC (2002) Modelling the transfers of training effects on performance in elite triathletes. Int J Sports Med 23:55-63

24. Peronnet F, Massicotte D (1991) Table of nonprotein respiratory quotient: an update. Can J Sport Sci 16:23-29

25. Phillips SM, Green HJ, Tarnopolsky MA, Heigenhauser G, Hill RE, Grant SM (1996) Effects of training duration on substrate turnover and oxidation during exercise. J Appl Physiol 81:2182-2191

26. Romijn JA, Coyle EF, Hibbert J, Wolfe RR (1992) Comparison of indirect calorimetry and a new breath $13 \mathrm{C} / 12 \mathrm{C}$ ratio method during strenuous exercise. Am J Physiol 263:E64-E71

27. Rundqvist H, Rullman E, Sundberg CJ, Fischer H, Eisleitner K, Ståhlberg M, Sundblad P, Jansson E, Gustafsson T (2009) Activation of the erythropoietin receptor in human skeletal muscle. Eur J Endocrinol 161:427-434

28. Shuai H, Zhang J, Zhang J, Xie J, Zhang M, Yu Y, Zhang L (2011) Erythropoietin protects pancreatic $\beta$-cell line NIT-1 cells against cytokine-induced apoptosis via phosphatidylinositol 3-kinase/Akt signaling. Endocr Res 36:25-34
29. Teng R, Gavrilova O, Suzuki N, Chanturiya T, Schimel D, Hugendubler L, Mammen S, Yver DR, Cushman SW, Mueller E, Yamamoto M, Hsu LL, Noguchi CT (2011) Disrupted erythropoietin signalling promotes obesity and alters hypothalamus proopiomelanocortin production. Nat Commun 2: 520

30. Thomsen JJ, Rentsch RL, Robach P, Calbet JAL, Boushel R, Rasmussen P, Juel C, Lundby C (2007) Prolonged administration of recombinant human erythropoietin increases submaximal performance more than maximal aerobic capacity. Eur J Appl Physiol 101:481-486

31. Tuzcu A, Bahceci M, Yilmaz E, Bahceci S, Tuzcu S (2004) The comparison of insulin sensitivity in non-diabetic hemodialysis patients treated with and without recombinant human erythropoietin. Horm Metab Res 36:716-720

32. van Loon LJ (2004) Use of intramuscular triacylglycerol as a substrate source during exercise in humans. J Appl Physiol 97: $1170-1187$

33. Xu B, G-h D, Liu H, Wang Y-q W, H-w JH (2005) Recombinant human erythropoietin pretreatment attenuates myocardial infarct size: a possible mechanism involves heat shock protein 70 and attenuation of nuclear factor-kappaB. Ann Clin Lab Sci 35:161-168

34. Yeo WK, Carey AL, Burke L, Spriet LL, Hawley JA (2011) Fat adaptation in well-trained athletes: effects on cell metabolism. Appl Physiol Nutr Metab 36:12-22 